\title{
EVOLUTION OF SARCOMA 180 \\ (ASCITIC TUMOR) IN MICE \\ INFECTED WITH SCHISTOSOMA MANSONI.
}

\author{
Fausto Edmundo Lima Pereira 1 , Pedro Raso ${ }^{2}$ and \\ Paulo Marcos Zech Coelho²
}

\begin{abstract}
Mice infected with 60 cercariae of Schistosoma mansoni were more resistant to the sarcoma 180 ascites tumor. Tumor inoculation was performed 50 days after schistosoma infection and the animals were observed and weighed at 48 hours intervals for development and progression of malignancy. In infected mice the weight gain (ascites formation) started later and was shorter than in uninfected controls. Also, the number of tumor cells into the peritoneal cavity $72 \mathrm{~h}$ after tumor implantation was shorter in infected group than in controls. This increased resistance against a transplantable tumor probably is related to the effect of endotoxin on tumoricidal activity of macrophages activated by the infection. The immunodepression induced by Schistosoma mansoni infection enhances the proliferation of endogenous bacteria increasing the amount of endotoxin absorbed from the gut.
\end{abstract}

Key Words: Experimental Schistosomiasis. Sarcoma 180. Schistosomiasis and cancer.

A relationship between Schistosoma infection and tumor development has been reported by some authors. Bladder cancer associated with Schistosoma haematobium was reported although an unequivocal statistical proof of this association has not been obtained ${ }^{4}$. A striking association between the giant follicular lymphoma of the spleen and schistosomiasis mansoni in hepatosplenic phase was found in Brazil $^{117}$. A possible association between lymphoreticular tumors and schistosomiasis is described from Nigeria ${ }^{6}$.

In experimental studies, mice with Schistosoma mansoni infection were injected with 2-amino-5azotoluene, a carcinogenic drug. The hepatomas appeared earlier and more frequently in infected animals than in respective uninfected controls 5 . Also, infected mice treated with a single dose of hycanthone developed hepatomas, whereas uninfected mice, treated with the same dose, did not ${ }^{7}$. However these observations showing a possible cocarcinogenic effect of $S$. mansoni infection were not corroborated by other investigators $^{21}$. The association of schistosomiasis

1. Departamento de Patologia Centro Biomédico UFES. Caixa Postal 780-29000 - Vitória - E. Santo - Brasil.

2. Grupo Integrado de Pesquisa em Esquistossomose ICBUFMG

Correspondencia para: Fausto Edmundo Lima Pereira Depto de Patologia, Centro Biomédico da Universidade Federal do Espírito Santo - Caixa Postal 780 - 29000 Vitória - E. Santo. Brasil.

This work was supported by CNPq and FINEP.

Recebido para publicação em 19/8/1985. and hepatocellular carcinoma is not proved ${ }^{19}$, although the geographical distribution of liver cancer in some countries corresponds to that of $S$. mansoni and Schistosoma japonicum infection ${ }^{15}$.

Finally, immunosuppression produced by Schistosoma mansoni infection is mentioned in several papers $^{2} 1418$. As the immune system plays an important role on the development of neoplasia, we studied the evolution of a transplantable tumor in Schistosoma mansoni infected mice. It was demonstrated, by injecting sarcoma 180 cells into the peritoneal cavity of $S$. mansoni infected and uninfected control mice, that schistosoma infection is unfavourable to tumor development.

\section{MATERIAL AND METHODS}

Male. randombred. albino mice weighing $32-38 \mathrm{~g}$ were used in the experiments. The mice were infected by subcutaneous injection of 50-60 Schistosoma mansoni cercariae (LE strain). Fifty days after schistosoma infection the animals were injected with $2 \times 10^{6}$ cells of sarcoma 180 , by the intraperitoneal route. The tumor cells were obtained from donor mice with ascitic tumor. Uninfected control mice, of the same age and weight, received the same dose of tumor cells.

The evolution of the tumor was followed up by: (a) weight gain after tumor implantation and (b) the counting of tumor cells into the peritoneal cavity 72 hours after tumor challenge. For evaluating weight gain, the animals were weighed at $\mathbf{4 8}$ hours time intervals. The difference between the initial weight (on 
the day of tumor implantation) and the weight after 48 $h$ indicates the weight gain. To count tumor cells in the peritoneal cavity, groups of five mice were killed after ether anaesthesia and, after injection of a known volume of cold Ringer solution, the peritoneal cells were removed by aspiration. The cells were counted in a haematocytometer after dilution in a $0.01 \%$ gentian violet solution in $5 \%$ acetic acid.

\section{RESULTS}

After four days in control mice the weight gain was a linear function of the time after four days after tumor implantation. The incubation period (the time when the weight gain started) was $4.3 \pm 1.2$ days. In Schistosoma mansoni infected animals the weight gain started 6 days after tumor implantation and was lower than in controls (where the incubation period was $6.1 \pm 1.8$ days). Counting of tumor cells in peritoneal cavity $72 \mathrm{~h}$ after tumor inoculation showed reduced development of tumor in infected mice. Data about the weight gain are summarized in the Figure 1 and the results of counting of tumor cells into the peritoneal cavity are shown in Table 1 .

Table 1 - Evolution of sarcoma 180 in mice infected with 60 cercariae of Schistosoma mansoninumber of tumor cells into the peritoneal cavity $72 \mathrm{~h}$ after implantation of $2 \times 10^{6}$ tumor cells on 50 th day after infection (six mice per group).

Number of tumor cells $\times 10^{6}$ (mean $\pm \mathrm{s}$ )

\begin{tabular}{cc} 
Control & Infected \\
$13.35 \pm 3.11$ & $7.85 \pm 2.23 *$ \\
\hline
\end{tabular}

$* \mathrm{p}<0.05$ ( t test $)$

The number of peritoneal cells exudated $72 \mathrm{~h}$ after tumor challenge was greater in infected mice. In control mice $60 \%$ of the cells were mononuclear; in infected mice there was a great number of polymorphonuclear leucocytes (neutrophils and eosinophils). The survival time after tumor implantation was similar in the two groups (17.5 \pm 2.2 days in controls and $16.7 \pm 2.9$ days in infected mice).

\section{DISCUSSION}

The evolution of sarcoma 180 in control mice occurred as it was expected: the ascite formation was a linear function of the time after four days of incubation period is the time interval between the tumor inoculation and the start of weight gain and is related to the number

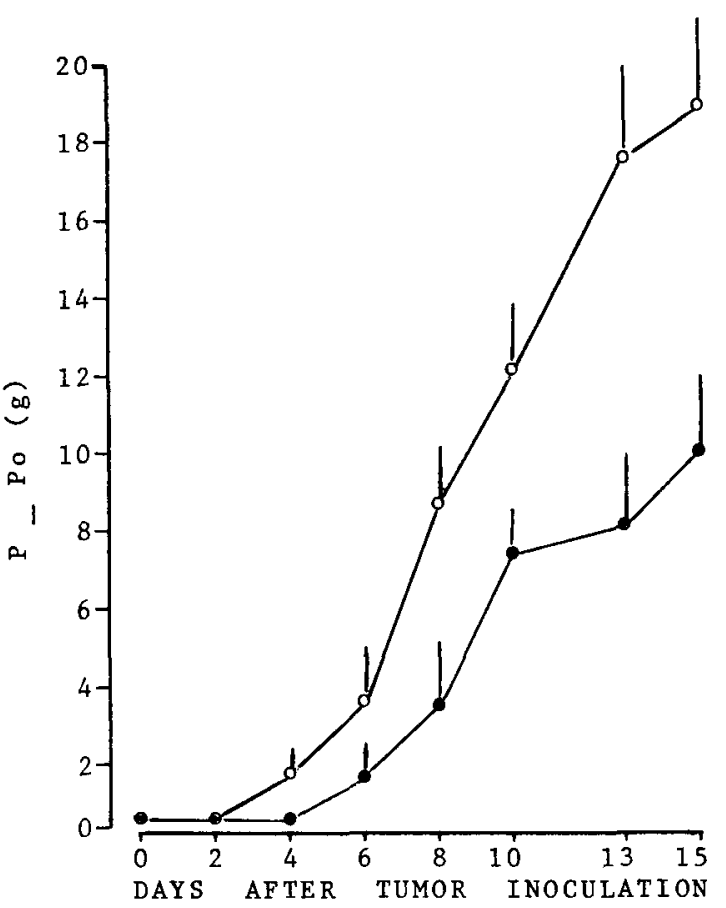

Figure 1 -Evolution of sarcoma 180 in mice infected with 60 cercariae of Schistosoma mansoni and inoculated with $2 \times 10^{6}$ tumorcells into the peritoneal cavity on day 50 after infection. Tumor evolution was evaluated by the weight gain $(P-P o ; P o=$ weight on day of tumor implantation and $P=$ weight in following days). The results are the mean \pm two standard deviations of ten mice per group.

$o=$ control $\bullet=$ infected with $\mathrm{S}$. mansoni.

of tumor cells inoculated ${ }^{10}$

In Schistosoma infected mice there was a reduction in tumor development, demonstrated by (a) an increased incubation period (higher than six days) and (b) a lowered number of tumor cells into the peritoneal cavity $72 \mathrm{~h}$ after tumor implantation.

We have not yet an explanation for these observations but in other helmintinic infections similar results were observed: mice infected with Trichinella spiralis are more resistant to the sarcoma $180^{1013}$. Also, in rats and mice infected with Nippostrongylus brasiliensis there is an increased resistanece to transplantable tumors 9 . In Trichinella spiralis infected mice there is immunosuppresion but there are evidences of macrophage activation and increased tumoricidal activity of peritoneal macrophages 1120 .

Schistosoma mansoni infection induce macrophage activation, beside the state of immunodepression and tumoricidal macrophages were demonstrated into the peritoneal cavity of three weeks 
Pereira FEL, Raso P, Coelho PMZ. Evolution of sarcoma 180 (ascitic tumor) in mice infected with Schistosoma mansoni. Revista da Sociedade Brasileira de Medicina Tropical 19: 39-42, Jan-Mar, 1986

infected mice, after intraperitoneal challenge with soluble schistosoma antigens ${ }^{8}$. On the other hand, the immunosuppression that follows Schistosoma infection could induce increased proliferation of endogenous bacteria, increasing the absorption of endotoxin. It is know that endotoxin plays an important role on the tumoricidal activity of activated macrophages $^{312}$. Endotoxin induces activated macrophages to produce the tumor necrosis factor that kill tumor cells but not normal cells ${ }^{3}$. Thus, the peritoneal macrophages in infected mice could kill more tumor cells than in controls, producing reduction in the inoculum dose. In this way the number of tumor cells into the peritoneal cavity $72 \mathrm{~h}$ after tumor inoculation could be lower in infected mice than in controls.

In spite the increased resistance against the sarcoma 180 cells found in Schistosoma mansoni infected mice, the life span in control and infected animals was similar. The similitude between the survival time of infected and control mice could tentatively be explained by two kinds of immunosuppressor stimuli acting together: the Schistosoma infection and the tumor implantation. In fact mice infected with 60 cercariae start to die around the $60^{\text {th }}$ day of infection. Also tumor injection induces reduction in the microbicidal activity of macrophages, enhancing opportunistic infection in tumor bearing mice ${ }^{16}$.

\section{RESUMO}

Camundongos infectados com 60 cercárias de Schistosoma mansoni tornaram-se mais resistentes ao sarcoma 180 na forma de tumor ascítico. A inoculação das células tumorais foi feita no $50^{\circ}$ dia de infecção e a evolução do tumor foi acompanhada através da pesagem dos animais com intervalos de 48 horas. Nos camundongos infectados o ganho de peso (formação da ascite) começou mais tarde e foi menor do que nos controles não infectados. Também o número de células tumorais na cavidade peritoneal 72 horas após a implantação do tumor foi menor no grupo infectado. Este aumento de resistência a um tumor transplantável possivelmente está relacionado ao efeito de endotoxinas sobre a atividade tumoricida dos macrofagos ativados pela infecção. A imunossupressão induzida pela infecção favorece a proliferacão de bactérias da flora endógena aumentando a quantidade de endotoxinas absorvidas pelo intestino.

Key words: Esquistossomose experimental. Sarcoma 180. Esquistossomose e Câncer.

\section{REFERENCES}

1. Andrade Z, Abreu WN. Follicular lymphoma of the spleen in patients with hepatosplenic schistosomiasis mansoni. American Journal of Tropical Medicine and Hygiene 20:237-243, 1971.

2. Araújo FG, Coelho PMZ, Pereira LH, Pellegrino J. Schistosoma mansoni: impairment of cell mediated immune response in mice. Clinical and Experimental Immunology 28:289-291, 1977.

3. Carswell EA, Old LJ, Kassel RI, Fiore N, Williamsom B. An endotoxin induced serum factor will cause necrosis of tumors. Proceedings of the National Academy of Sciences (USA) 72:3666-3670, 1975.

4. Cheever AW. Schistosomiasis and neoplasia. Journal of the National Cancer Institute 61:13-18, 1978.

5. Domingo ED, Warren KS, Stenger RJ. Increased incidence of hepatoma in mice with chronic schistosomiasis treated with a carcinogen. American Journal of Pathology 51:307-321, 1967.

6. Edington GM, von Lichtenberg F, Nawabuebo I, Taylor JR, Smith JN. Pathologic effects of schistosomiasis in Ibadan, Western State of Nigeria. I-Incidence and intensity of infection. Distribution and severity of lesions. American Journal of Tropical Medicine and Hygiene 19:982-985, 1970.

7. Haese WH, Smith DL, Bueding E. Hycanthone induced hepatic changes in mice infected with Schistosoma mansoni. Journal of Pharmacology and Experimental Therapheutics 186:430-440, 1973.

8. James SL, Ladins JK, Meltzer MS, Sher A. Macrophages as effector cells of protective immunity in murine schistosomiasis. I-Activation of peritoneal macrophages during natural infection. Cellular Immunology 67:255266, 1982.

9. Keller R, Ogilvie BM, Simpson E. Tumor growth in nematode infected animals. Lancet 1:678-680, 1971.

10. Lubiniecki AS, Cypess RH. Quantitative studies of effect of previous Trichinella spiralis infection on sarcoma 180 ascites tumor. Tropenmedizin und Parasitologie 26:329-334, 1976.

11. Meerovitch E, Bomford R. Macrophage potentiation by Trichinella spiralis. Annals of Tropical Medicine and Parasitology 71:245-251, 1977.

12. Meltzer MS, Rucco LP, Boraschi D, Nacy CA. Macrophage activation for tumor citotoxicity: analysis or intermediary factors. Journal of Reticuloendothelial Society 26:403-415, 1979.

13. Molinari JA, Garrick L, Lubiniecki AS. Influence of Trichinella spiralis infection on development of sarcoma 180 ascites tumor. Tropenmedizin und Parasitologie 30:439-441, 1979.

14. Mota-Santos TA, Gazzinelli G, Ramalho-Pinto FJ, Pellegrino J, Silva WD. Immunodepression in mice following Schistosoma mansoni infection. Revista do Instituto de Medicina Tropical de São Paulo 18:246250,1976 .

15. Mott KE. Possible relationship of Schistosoma infection and liver carcinoma. Transactions of the Royal Society of Tropical Medicine and Hygiene 72:552-553, 1978.

16. North RJ, Kirstein DP, Tutle RL. Subversion of host defense mechanisms by murine tumors. I. A circulating factor that suppresses macrophage mediated resistance to infection. Journal of Experimental Medicine 143:555$562,1976$. 
Pereira FEL, Raso P, Coelho PMZ. Evolution of sarcoma 180 (ascitic tumor) in mice infected with Schistosoma mansoni. Revista da Sociedade Brasileira de Medicina Tropical 19: 39-42, Jan-Mar, 1986

17. Paes AP, Marigo C. Linfoma folicular gigante do baço e esquistossomose mansônica. Revista do Instituto de Medicina Tropical de São Paulo 23:287-292, 1981.

18. Peley RP, Ruffier JJ, Warren KS. The suppressive effect of a chronic helminthic infection Schistosomiasis mansoni on the in vitro response of spleen and lymphnode cells to the T cell mitogens PHA and Con A. Infection and Immunity 13:1176-1183, 1976.

19. Pereira FEL, Gonçalves CS. The association of Schistosoma mansoni infection with hepatocellular carcinoma. Revista da Sociedade Brasileira de Medicina Tropical 17:73-76, 1984.

20. Wing ES, Krahenbuhl JL, Remington JS. Studies of macrophage function during Trichinella spiralis infection in mice. Immunology 36:479-485, 1979.

21. Yarinski A, Drobeck HP, Freele H, Wiland Y, Gumaer KI. An 18 month study of the parasitologic and tumorigenic effect of hycanthone in Schistosoma mansoni infected and non infected mice. Toxicology and Applied Pharmacology 27:169-182, 1974. 